\title{
Contemporary Concepts of Root System Architecture of Urban Trees
}

\author{
Susan D. Day, P. Eric Wiseman, Sarah B. Dickinson, and J. Roger Harris
}

\begin{abstract}
Knowledge of the extent and distribution of tree root systems is essential for managing trees in the built environment. Despite recent advances in root detection tools, published research on tree root architecture in urban settings has been limited and only partially synthesized. Root growth patterns of urban trees may differ considerably from similar species in forested or agricultural environments. This paper reviews literature documenting tree root growth in urban settings as well as literature addressing root architecture in nonurban settings that may contribute to present understanding of tree roots in built environments. Although tree species may have the genetic potential for generating deep root systems ( $>2 \mathrm{~m})$, rooting depth in urban situations is frequently restricted by impenetrable or inhospitable soil layers or by underground infrastructure. Lateral root extent is likewise subject to restriction by dense soils under hardscape or by absence of irrigation in dry areas. By combining results of numerous studies, the authors of this paper estimated the radius of an unrestricted root system initially increases at a rate of approximately 38 to 1 , compared to trunk diameter; however, this ratio likely considerably declines as trees mature. Roots are often irregularly distributed around the tree and may be influenced by cardinal direction, terrain, tree lean, or obstacles in the built environment. Buttress roots, tap roots, and other root types are also discussed. Key Words. Root Depth; Root Extent; Root Restriction; Urban Forestry; Woody Plants.
\end{abstract}

Tree roots are supply lines for water and minerals, play important roles in carbohydrate storage and hormonal signaling, and physically anchor trees in the ground (Kozlowski and Pallardy 1997). To perform these functions, roots must be able to explore their environment and maintain their health. A root system has the potential to draw water and mineral resources from the soil it explores, so how the root explores its environment affects potential resource acquisition. In urban settings, the belowground environment is often inhospitable and restrictive to tree root growth. Impediments to a healthy root system are frequently pointed out as the underlying cause for a wide array of tree growth and health problems (e.g., Patterson 1977; Hawver and Bassuk 2006). Thus one seeks to understand how root systems develop and respond in this environment. This knowledge is essential for comprehending how trees grow in urban and landscape settings and how belowground features of the built environment, including landform, structures, and urban soils, interact with tree roots.

The study of trees is a vast area of scientific inquiry, yet the study of urban trees represents only a fraction of published research. In this review, the term "urban trees" refers to trees growing amongst buildings or other structures for human use regardless of overall land use. Thus the discussion may be germane to trees growing around a visitors' center at a national park, but may not be relevant to trees in a forest fragment within a large city. Roots are always difficult to study, simply because they are under ground and respond to localized environmental changes. These difficulties are exacerbated in urban trees because of the variety of circumstances where trees are grown. Earlier reviews of urban tree root systems (e.g., Perry 1982; Gilman 1990) have helped shape arboriculture research and practice for many years. More recent reviews have focused on specific aspects of root system development (e.g., Crow 2005). The aim of this paper is to present a survey of literature that is relevant to urban tree root systems around the world as well as to take a fresh look at these earlier works about urban tree root systems in the context of recent research. In addition to readily available sources, the authors made a concerted effort to uncover research from underrepresented arenas, including reports from various geographical regions in the world and research investigating root systems of urban trees.

The objectives here are to:

* Critically evaluate and present the current state of knowledge on tree root architecture in urban and landscape settings including depth and extent of root systems in a way that is useful to both researchers and practitioners.

* Identify knowledge gaps in this arena.

* Based on these knowledge gaps and the utility of past research results, propose areas where further research is a priority.

\section{TREE ROOT STRUCTURE AND FUNCTION}

Terminology used to describe tree roots is very diverse and not standardized. In their compendium of root system terminology, Sutton and Tinus (1983) defined more than 2,200 root terms, illustrating the wide variety of ways to describe tree roots. Classification of roots has historically been based on their anatomical or functional characteristics (Sutton and Tinus 1983; Kozlowski 
and Pallardy 1997). Anatomically, roots can be fundamentally classified as woody or nonwoody (e.g., Lyford and Wilson 1964). Woody roots are those that have undergone secondary growth, resulting in rigid structure and perennial lifespan. Functionally, these roots are often referred to as structural roots (see Sutton and Tinus 1983), acknowledging their role in anchoring the tree and creating a framework for the root system. Typically, a tree has 5-15 (or more) primary structural roots that emanate from the root collar and descend obliquely into the soil before becoming horizontal within a short distance of the trunk, although the pattern of root development can vary considerably. The area within 1-2 $\mathrm{m}$ of the trunk on larger trees is frequently referred to as the zone of rapid taper because structural roots found there often exhibit considerable secondary thickening not present on roots farther from the trunk (see Wilson 1964). Wilson (1964) additionally reviews the development of this zone and its relation to mechanical stability. Near the trunk juncture, structural roots on large trees may become thickened eccentrically in the vertical plane and are thus termed buttress roots, reflecting their shape and stabilization function (Sutton and Tinus 1983). These roots may have smaller diameter vessels than those found in the more rope-like roots found farther from the trunk (Wilson 1964). Although reaching phenomenal proportions on tree species in tropical forests, buttress roots are more modest on temperate tree species. The presence of pronounced buttress roots has been associated with soils that offer poor anchorage and trees that lack tap roots (see Henwood 1973), but other studies have found taproots on both buttressed and unbuttressed tropical trees (Crook et al. 1997). It is generally believed that the eccentric shape of buttress roots more effectively distributes mechanical stress on the root system [see Mattheck (1991) for a theoretical discussion; and Clair et al. (2003) for an empirical study of buttress roots and mechanics] and serve both tension and compression roles in stabilization (Crockett et al.1997). In some tree species, horizontal structural roots near the trunk produce sinker roots that plunge vertically into the soil, providing supplemental anchorage (Ghani et al. 2009).

Beyond the zone of rapid taper emanates a framework of woody structural roots that provide additional anchorage and serve as conduits for long distance transport of water, nutrients, and metabolites. The size of these roots may be influenced by mechanical stresses, with more large roots forming in the windward and leeward directions in trees subjected to winds from one direction (Stokes et al. 1995). Tree stability in urban settings is critically important. In Singapore, for example, $20 \%$ of tree failures have been attributed to uprooting (Rahjardo et al. 2009). Limited information is available about how urbanized sites affect root anchorage, although it can be expected that whenever root architecture is altered, such as by an urban growing environment, there is the possibility that tree anchorage could be affected. Physically confined planting holes must necessarily limit the development of buttress roots, for example. In addition, the wide variety of specialized soil mixes used in urban settings undoubtedly have different shear strengths, further altering the behavior of root systems as tree anchors. For example, Rahardjo (2009) found that an 80:20 mix of soil and granite chips, akin to a structural soil, enhanced tree resistance to uprooting. Although structural roots comprise most of the root biomass, they account for a small percentage of total root length and root surface area.

Root surface area is instead dominated by an extensive network of "nonwoody" roots, so called because they have not un- dergone secondary growth, proliferating from the structural root framework. Functionally, these roots are often referred to as fine or absorbing roots, acknowledging their primary role in water and nutrient uptake. These roots are generally small in diameter $(<2 \mathrm{~mm})$, have high metabolic rates, and have a lifespan that ranges from a few days to weeks (Black et al. 1998; Pregitzer et al. 1998; Pregitzer et al. 2002). In addition to uptake, nonwoody roots are the primary location of root hormone synthesis, nutrient assimilation, root exudation, and symbiosis with soil microorganisms (Smith 1976; Marschner 1996; Guo et al. 2008). Among these fine roots, function is variable and is often determined by position on the root system hierarchy (Pregitzer 2002; Pregitzer et al. 2002; Guo et al. 2008). First-order roots (the ultimate root tip) are the most likely point for mycorrhizal colonization and consistently have higher nitrogen $(\mathrm{N})$ levels than higher order roots (Pregitzer et al. 2002). These fine roots require the least investment of carbon (C) to grow, but are the most metabolically costly for trees to maintain on a mass basis. Nonetheless, they provide the most plasticity for trees in responding to nutrient and water resources in the soil (Pregitzer et al. 2002). Despite their diminutive stature, fine roots can account for as much as $90 \%$ of total root system length (Roberts 1976). Indeed, firstorder fine roots may have considerably greater root length density than other fine roots (Wang et al. 2006). Some nonwoody roots eventually undergo secondary development to become woody, structural roots and contribute to the root system framework, but most perish and are replaced (Fahey and Hughes 1994).

\section{ROOT SYSTEM DEPTH AND SPREAD}

"Where are the roots?" is a fundamental question in arboriculture and urban forestry. Estimating root depth and spread is a prerequisite for many arboricultural practices, such as tree preservation, and guides a wide range of research decisions. Although advances in remote detection technologies, such as ground-penetrating radar (e.g., Nadezhdina and Cermak 2003; Hirano et al. 2009) may enable accurate determination of root location in the future, rules of thumb are typically relied upon for estimating root extent and depth. Typical rules found in texts and educational materials estimate root spread as up to $3 \times$ canopy spread (e.g., Elmendorf et al. 2005) or 1-1.5 $\times$ tree height (e.g., Mariotte, undated.) The exact origins of these rules are unclear or multiple, but may originate from studies with young nursery trees (e.g., Gilman 1988) and from early studies at Harvard Forest on four Acer rubrum (red maple) trees (Wilson 1964), respectively. Tree protection zones for sensitive older specimens are prescribed as a ground radius of $0.18 \mathrm{~m}$ per $\mathrm{cm}$ of trunk diameter (Harris et al. 2004); presumably this is intended to encompass the vast majority of the root system. Depth, described less consistently in educational publications, is sometimes vaguely described as being primarily or concentrated in the upper $0.3 \mathrm{~m}$ of soil, or as having the majority of fine roots in this region (Gilman 2003; Elmendorf et al. 2005).

\section{Root Depth}

Inconsistencies in descriptions of root depth may reflect variability in soil profiles across landscapes (Coile 1937), as well as differences among tree species. Crow (2005) provides a concise review. There is certainly a tendency for roots to exploit upper soil regions (Wilson 1964; Crow 2005; Wang et al. 2006), and roots of deeply planted trees have been observed to quickly rise 
to the soil surface and adopt a more typical depth distribution as they extend from the tree (e.g., Day and Harris 2008). In addition to limiting soil conditions below, the presence of turfgrass has been associated with reduced tree fine root development in upper soil regions (Watson and Himelick 1982), perhaps limiting root development from above. Roots are opportunistic and will grow wherever environmental conditions permit. Species may differ in their foraging strategies, either proliferating in nutrient-rich pockets, or extending widely to explore the largest soil volume possible (Mordelet et al. 1996; Mou et al. 1997; Huante et al. 1998). Mordelet et al. (1996) found that mature palms (Borassus aethiopum) extended roots as far as $20 \mathrm{~m}$ before encountering a nutrient-rich soil patch where root proliferation was ten times that in ordinary soil. The roots of palms are likely not representative of hardwoods or conifers, but the same localized proliferation has been observed in Liquidambar styraciflua (sweetgum) (Mou et al. 1997). An analogous foraging opportunity presented in an urban environment might be when a broken seal in a sewer pipe creates a soil patch rich in water and nutrients-a common occurrence in cities (Rolf 1991; Randrup et al. 2001; see Schroeder 2005 for photographic documentation of such an instance). Not surprisingly, however, the ecology of root foraging has not been studied systematically in urban environments. For urban trees, three root depth issues are of particular interest: (1) Can root depth be influenced by species selection-is it under genetic control? (2) How deep can urban tree roots reach? (3) What role do deep roots play relative to surface roots in terms of resource acquisition?

Rooting depth varies among species in similar conditions (Watson and Himelick 1982; Jackson 1999); whether there is genetic control over root depth, independent of species' environmental tolerances is less clear. This is of considerable interest for urban forestry. For example, if rooting depth can be controlled genetically, then deep-rooting trees could be selected to minimize conflicts with pavement. There is evidence for this genetic control, but tolerances of soil conditions such as moisture (Hosner 1960; Hook and Brown 1973) and pH (Martin and Marks 2006) vary-even within a species - and it may be difficult or impossible to separate the influence of genetics on root architecture from the influence of genetics on tolerance of soil conditions, since these conditions also have a tendency to vary with depth.

Species differences in rooting depth within the same environment have been documented. For example, a study in Texas, U.S., linked roots penetrating underground caverns to surface vegetation using DNA sequence variation (Jackson 1999). Roots of Quercus fusiformis (Texas live oak) were consistently present in the deepest caves, with water uptake by roots verified at $25 \mathrm{~m}$ depth. On one site, Jackson (1999) found Q. fusiformis was the only species with roots that penetrated to $14 \mathrm{~m}$, even though surface vegetation included other species, such as Q. stellata (post oak), with similar environmental tolerances (Stransky 1990). Whether the ability of $Q$. fusiformis to grow extremely deep roots in these environments reflects genetic control of geotropic response (i.e., directional growth in response to gravity), or simply genetic control of tolerance for soil environmental conditions is not known. Burger and Prager (2008) explored this question in a recent study addressing whether root architecture could be preserved in clones created through vegetative propagation. One species, Pistacia chinensis (Chinese pistache), clearly formed deeper root systems than two other species, Fraxinus uhdei (shamel ash) and Zelkova serrata (Japanese zelkova), when planted in a $2 \mathrm{~m}$ deep Yolo loam. How- ever, when shallow- and deep-rooted genotypes from within the same species were selected and propagated vegetatively, their depth-of-rooting characteristic was not conveyed to their clones. Suspecting differences in geotropic response among root types, Burger and Prager (2008) surmised that the effect of vegetative propagation on root architecture may have obscured any genetic control of rooting depth. Vegetative propagation by cuttings depends upon adventitious roots being generated from the cut stem, which in some cases has been linked to shallower root systems (Yamashita et al. 1997; Mulatya et al. 2002). When the orientation of clonal tea plants (Camellia sinensis) grown in windowed boxes was altered, seminal roots displayed more pronounced geotropic response than adventitious and lateral roots (Yamashita et al. 1997). This behavior was linked to a more pronounced presence of amyloplast particles in the root cap of seminal roots. However, instances of deeply rooted vegetatively propagated trees have also been recorded. For example, tap roots of clonal Pinus taeda (loblolly pine) propagated by rooting cuttings, penetrated downward more than $2 \mathrm{~m}$ in a sandy clay loam soil (Fairview series) in the Piedmont region of Virginia, U.S. (Jeremy Stovall, pers. comm.). P. taeda typically forms tap roots, so there is a genetic propensity for such root architecture (Baker and Langdon 1990). Nursery production, regardless of propagation technique, alters root system architecture in various ways (see Day et al. 2009; Hewitt and Watson 2009). However, whether the tendency toward shallower root systems persists in mature urban trees has not been studied, and the relative influence of propagation and production factors in relation to soil environmental conditions remains unknown.

How deep are tree roots of urban and landscape trees? Several surveys documenting tree root depth have been published. Each review, however, has a different scope and intent, and results must be considered in such a light (e.g., Stone and Kalisz 1991; Schenk 2002). Stone and Kalisz (1991), for example, conducted a comprehensive survey of literature and observations reporting maximum rooting depth for more than 1,000 trees from dozens of species of different ages in hundreds of different settings, but summarized studies are almost entirely from forest or orchard settings. In addition, the methods of the collected research vary dramatically with many only entailing partial sampling or excavations. This is understandable because excavating tree roots is extremely laborious, and if the research question at hand can be answered with limited excavation (e.g., to $60 \mathrm{~cm}$ ), then such excavating will prove to be the appropriate technique. Thus, in all but few cases (e.g., Lyford and Wilson 1964), root depth and distribution research on larger trees must be interpreted with caution, as it is generally impossible to follow every tree root to its tip. Indeed, although Lyford and Wilson (1964) excavated entire roots of Acer rubrum to their tips and documented all breaks where the tip was not found, the natural result is that only two trees were successfully excavated. Thus, literature reviews by necessity combine results from many different types of studies. Occasionally, a special occurrence, such as a storm that uproots trees, allows a methodologically consistent survey of root systems, but generally only a portion of the root system may be studied (e.g., Glasson and Cutler 1990). Interpretation of potential tree root spread is subject to the same limitations as root depth. Nonetheless, summary analyses provide a sense of the range of rooting depths across environments and are helpful for understanding the potential for soil exploration and infrastructure invasion by tree roots. 
Stone and Kalisz (1991) found the shallowest maximum rooting depth of any tree surveyed to be $1 \mathrm{~m}$, and the deepest exemplar surveyed was $61 \mathrm{~m}$. Although open-grown or "horticultural" trees were included in this survey, results were not categorized by forest versus urban growing sites, and most of the horticultural examples were in orchards or other production agriculture settings. Although urban soils are heterogeneous and can defy generalization, it is common to find impenetrable horizons relatively near the surface; examples include buried asphalt, subsoils compacted by construction activity, and poorly drained horizons. Analogous conditions in forest settings (e.g., bedrock, hardpans, shallow water tables) result in shallower root systems than occur for the same species on less restrictive sites (Lyford and Wilson 1964; Stone and Kalisz 1991). Soil compaction is very common in urban areas and can result in severe root restriction (Alberty et al. 1984; Day et al. 2000). Species interaction with the environment plays a role here as well. Certainly there are instances of deep-rooted urban trees where conditions allow. For example, tree roots on the highly urbanized campus of the University of Costa Rica (San Jose, Costa Rica) were observed to penetrate several meters deep (personal observation of the authors). Similarly, roots of Celtis laevigata (hackberry) and Ulmus americana (American elm), common urban species in the U.S., have been found in natural settings at $6 \mathrm{~m}$ and $7 \mathrm{~m}$ depths, respectively (Jackson 1999), and young Populus tomentosa (Chinese white poplar) up to 14-years-old in Hebei Province in China were found to have root systems extending as much as $4.5 \mathrm{~m}$ deep in a sandy soil (Wong et al. 1997).

These studies and others (e.g., Stone and Kalisz 1991), indicate that some tree species commonly used in urban settings have the potential for rapid development of deep root systems. Do these species realize this genetic potential for exploration of deeper soil regions when planted in urban and landscape settings? Deep root systems have the potential to both exploit groundwater (Dawson 1996), and redistribute groundwater stores through hydraulic lift (Dawson 1993; Burgess et al. 1998), a process to which is attributed the ability of stands of young Acer saccharum (sugar maple) to obtain as much as $17 \%$ of their water supply from groundwater (rather than soil water originating from rainfall), during extended dry conditions. Urban trees frequently experience drought, but whether conditions can be created where urban trees can access deep groundwater stores has yet to be explored, and no instances of hydraulic lift in urban settings have been documented.

\section{Root Spread}

Many rules of thumb have been offered for estimating root spread in urban trees. Ratios of height, trunk diameter (typically "diameter at breast height" or approximately $1.3 \mathrm{~m}$ ), and canopy diameter may be used for root system spread estimation (e.g., Smith 1964; Gilman 1988; Gerhold and Johnson 2003), but the accuracy of these methods can depend upon the species or cultivar (Gilman 1988), tree vigor (Balasubramanyan and Manivannan 2008), and the rooting environment (Gerhold and Johnson 2003). Moreover, estimates of root spread generally assume there are few physical impediments to root extent. This is rarely the case in very urbanized settings. For example, root system spread may be halted within approximately $10 \mathrm{~cm}$ after penetrating beneath roadways or sidewalks (Gerhold and Johnson 2003). Even where soil conditions are homogeneous, roots may not be uniformly distributed around the tree (Tubbs 1977; Watson Himelick 1982; Ghani et al. 2009).
Root spread studies must also be interpreted with caution due to the potential methodological discrepancies as previously described.

\section{Tree height as a predictor of root spread}

How reliable is tree height for estimating root spread of urban and landscape trees? Open-grown trees have been documented to have wider root spread than forest-grown trees of the same species when considered as a function of tree height (Smith 1964). Drier sites have in some cases been observed to result in wider spreading root systems (Smith 1964; Belsky 1994). For the current study, the authors combined available published data (Appendix), including several examples from urban sites, to analyze the predictive capacity of tree height for root system radius using regression analysis (SigmaPlot v. 9.01, Systat Software, Inc., Chicago, IL) (Figure 1). Of the studies analyzed, tree height explained only $36 \%$ of the variation in root spread; however, the power of this analysis is limited by the dearth of published data. Yet, even with large numbers of trees of the same species and in the same region, Smith (1964) found that only $33 \%-50 \%$ of the variation in root spread could be explained by height. Although the relationship established in Figure 1 is approximately 1:1, it is instructive that almost none of the data points fall within the $95 \%$ confidence inter$\mathrm{val}$; thus for an individual tree, there is no assurance that any root estimate based on height will be accurate. In summary, tree height is a poor predictor of root spread in urban and landscape settings.

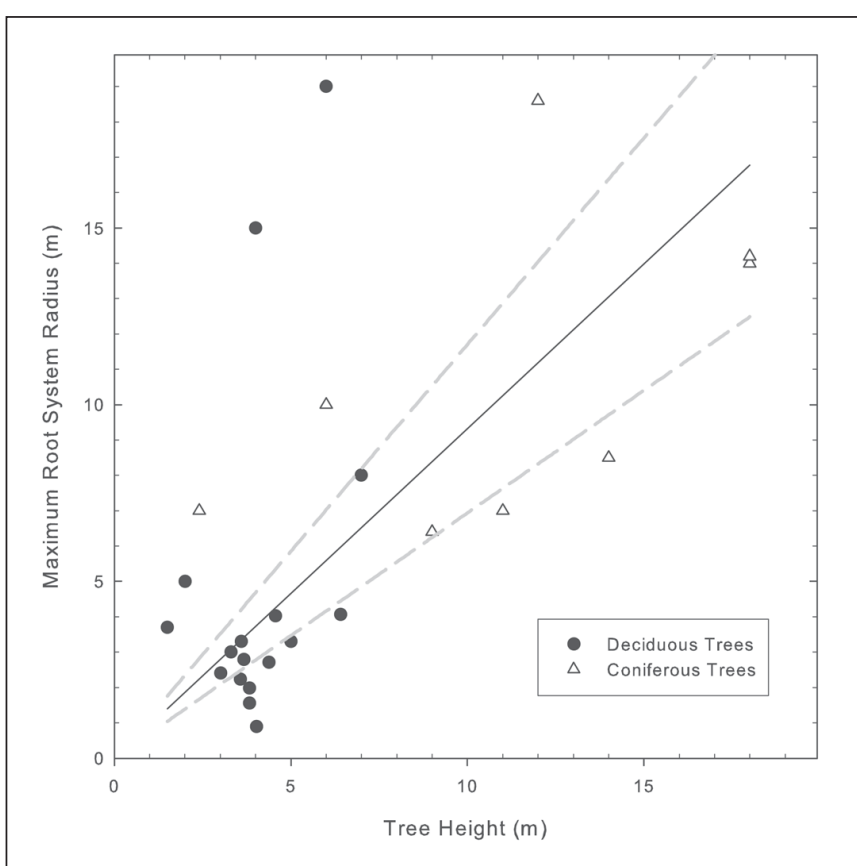

Figure 1. The relationship between tree height and maximum root radius from summarized literature. $R^{2}=0.359$ and $p=0.002$. Dashed lines represent $95 \%$ confidence interval. When data for conifers and deciduous species were analyzed separately, data was transformed to achieve a more constant variance and relationships were as follows: Deciduous: $p=0.25$ and $R^{2}=0.09$ Conifers: $R^{2}=0.28 p=0.18$. Each data point represents a study average, see Appendix for data sources and $\mathrm{N}$ values. 


\section{Canopy diameter as a predictor of root spread}

Canopy diameter is convenient for purposes of visually estimating tree root spread, but the relationship between canopy and roots is highly species dependent (Tubbs 1977; Gilman 1988). In one study, the largest roots of young nursery trees were excavated to their full length and the relationship between canopy and root spread determined (Gilman 1988). Root system diameter averaged 2.9 times the diameter of the canopy, but ranged from 1.68 times the canopy for Fraxinus pennsylvanica (green ash) to 3.77 for Magnolia grandiflora (Southern magnolia), and in Quercus virginiana (live oak), no relationship could be established. In a study of young forest trees on a clearcut, Acer saccharum (sugar maple) average root spread (not the maximum) was found to equal canopy spread, while in Betula allegheniensis (yellow birch) the average root spread was greater than canopy spread (Tubbs 1977). In addition to species variation, root spread may not be symmetrically situated beneath the canopy, even in unrestricted soil, especially if a tree is leaning. For example, Tubbs (1977) documented root systems that were approximately the same diameter as the canopy spread, but the distribution was not directly beneath the canopy-one side of the root system extended far beyond the dripline while the other side extended much less than half the canopy diameter. Tubbs (1977) also observed the root systems were generally distributed away from the lean of the tree. A similar phenomenon has been observed for trees on slopes: a majority of the root system may be located on the uphill side of the tree (Di Iorio et al. 2005). All reviewed studies relating tree canopy and root system spread used trees less than $18 \mathrm{~cm}$ in trunk diameter, meaning it is possible these relationships would change for mature trees. In summary, canopy spread is not likely to be a successful predictor of root spread unless a relationship is established for a particular species and it is clearly recognized that root distribution may not correspond to canopy distribution. Even then, these relationships may not hold for older trees.

\section{Trunk diameter as a predictor of root spread}

Trunk diameter is often used to estimate tree root spread; municipal ordinances frequently specify this method for determining tree protection zones (TPZs) and ensuring adequate soil resources for preserved trees. For the current study, the authors employed nonlinear regression to investigate the relationship between trunk diameter and maximum root spread using available published data (Figure 2). A much stronger relationship $\left(\mathrm{R}^{2}\right.$ $=0.89$ ) was found when relating root spread to trunk diameter rather than tree height. The relationship reaches an asymptote at approximately $25-30 \mathrm{~cm}$ of trunk diameter. Analysis of the linear portion of the regression (0-20 cm trunk diameter range) determined the average ratio of predicted root system radius to trunk diameter is $38: 1$. Thus on young trees, root system radius may increase by $38 \mathrm{~cm}$ for every $\mathrm{cm}$ of trunk diameter. However, on older trees, this relationship changes, and root extent increases very slowly relative to trunk diameter. Most, but not all, of the species assessed were medium or large-stature trees, and all were trees that experience secondary growth (i.e., not palm trees). It would be expected that smaller stature species would exhibit diminished root system expansion at a smaller trunk diameter.

The strong relationship between trunk diameter and root spread shown above supports the practice of designating TPZs based on trunk diameter. Harris et al. (2004) suggest suitable
TPZs have a ratio anywhere from 6:1 (radius of TPZ:trunk diameter) for young or tolerant trees, to $18: 1$ for old trees of sensitive species (note these ratios are unitless). According to the authors' predictive model, prescribing a TPZ on the low end of this scale protects a relative small portion of the root system. Thus, at young ages, root systems would only be partially protected. As trees age and become more vulnerable to injury from disturbance, more of the root system would be included in the TPZ. On very large and old trees, it is likely that the entire root system should be protected, even allowing for some irregularities in root distribution, which would be wise given their relative intolerance of root disturbance. In summary, trunk diameter can provide a reasonable estimate of tree root spread as long as one recognizes: 1) individual trees will vary from the estimate, perhaps considerably; 2) root spread may be irregular and not uniformly distributed around the trunk, especially when trees are leaning or located on a slope; and 3) physical constraints, such as confined urban planting pits (Gerhold and Johnson 2003), or other structures may limit root growth in certain dimensions.

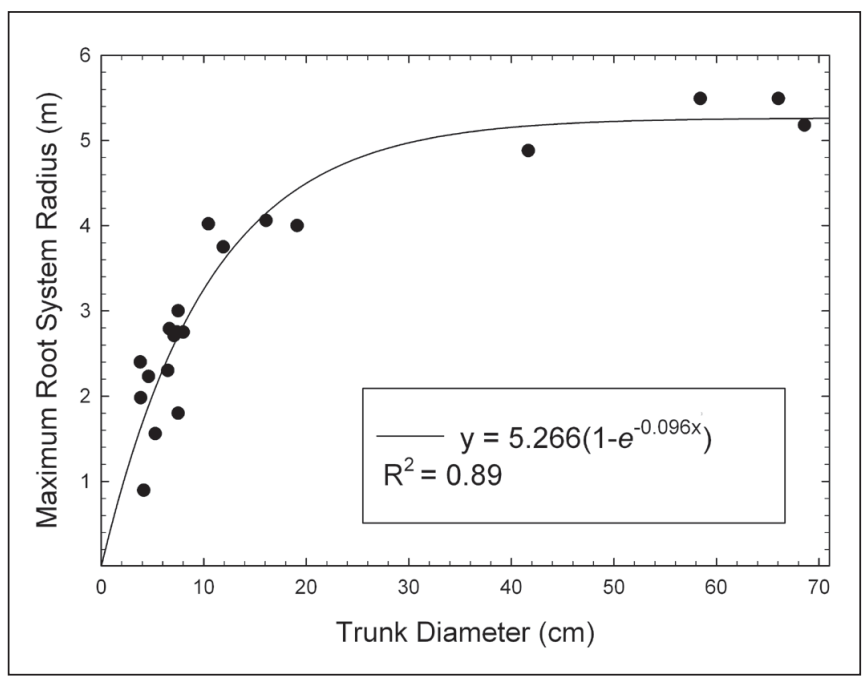

Figure 2. The relationship between trunk diameter and maximum root radius from summarized literature. Each data point represents a study average, see Appendix for data sources and $\mathrm{N}$ values.

\section{CONCLUSIONS AND FUTURE RESEARCH}

Root depth and extent can be severely limited and highly irregular in urban settings. When root restrictions are minimal, root spread shows a strong relationship with trunk diameter, which is a more reliable predictor than canopy diameter or tree height. During the first part of a tree's lifespan, the ratio of root system radius to trunk diameter is about 38:1. However, considerable variation can be expected due to species and site conditions. Expansion of the root system relative to trunk growth appears to slow down as a tree matures. Root depths greater than $2 \mathrm{~m}$ have been documented for several urban species, and genetic control over rooting depth is evident within species. Nonetheless, urban sites frequently restrict rooting depth, and vegetative propagation of deep-rooted selections has not been successful. Deep roots may confer a number of advantages including the acquisition of additional water and mineral resources, potential for 
hydraulic lift, and avoidance of conflicts with pavement. Root architecture and its interactions with soil properties influence tree stability, which has serious implications in urban settings.

This review has focused on the architecture of tree roots in the urban environment, particularly vertical and horizontal extent. How does this knowledge guide future research? There are many unanswered questions that relate to management of urban tree root systems, but here the authors confine comment to basic research questions to provide a greater understanding of the characteristics of the urban tree root system. The authors propose the following as possible areas of future research:

\section{Root Architecture and Exploration of the Built Environment}

Although the rhizosphere is traditionally understood as the plane of contact between roots and soil where the soil environment is dominated by root activity, rhizosphere here is considered in a broader sense to be the root-soil ecosystem. If both roots and soil are present, they cannot be viewed in isolation. What belowground situations allow for the greatest root exploration? Can this knowledge help advance techniques for avoiding tree-infrastructure conflicts? Although initial investigations indicate that selecting trees for their propensity for deep rooting may have limited success, further investigation is merited in this area because possible benefits are considerable. In addition, investigation of the genetic control of other facets of root architecture that may confer an advantage to urban trees (e.g., root systems that are more fibrous or regenerate more rapidly), may allow for selection of trees that can better exploit limited soil resources in urban settings.

\section{Resource Acquisition by Urban Tree Roots}

Urban trees may be exposed to long periods of drought, especially if global temperatures increase in the future. Urban species have the potential to grow deep roots, but are frequently limited by the soil environment. How can site design favor greater root exploration? If site design allowed for deep roots, would phenomena such as hydraulic lift allow for protection of vegetation during dry periods? Would drought tolerance be increased? Could access to nutrients and water be managed or engineered more effectively?

\section{Mechanical Stability}

If society is successful in growing large trees in the built environment, then research is needed on what root architecture characteristics are essential for tree stability and how the development of these characteristics can be assured. In addition, engineered soils and designed substrates are increasingly common and need to be evaluated in the context of tree stability.

Acknowledgments. We are grateful to many people for their contributions of literature, resources, and advice to this project. We especially thank Julia Bartens, Francesco Ferrini, Ed Gilman, Brian Kane, Greg McPherson, Paul Markworth, Tang Dai, Gary Watson, Larry Costello, and Lisa Richardson-Calfee. This project was supported in part by the International Society of Arboriculture and is part of the ISA Literature Review Series.

\section{LITERATURE CITED}

Adams, M.E. 1966. A study in ecology of Acacia mellifera, A. seyal and Balanites aegyptiaca in relation to land-clearing. Journal of Applied Ecology 4:221-237.

Alberty, C.A., H.M. Pellett, and D.H. Taylor. 1984. Characterization of soil compaction at construction sites and woody plant response. Journal of Environmental Horticulture 2(2):48-53.

Baker, J.B., and O.G. Langdon. 1990. Pinus taeda L. — loblolly pine. pp. 497-512. In: Silvics of North America: Volume 1. Conifers. Vol. Agriculture Handbook 654. R.M. Burns and B.H. Honkala (Ed.). United States Department of Agriculture (USDA), Forest Service

Balasubramanyan, S., and M.I. Manivannan. 2008. Root pattern studies in acid lime in silt clay soils. The Asian Journal of Horticulture 3(2):241-245

Ballantyne, A.B. 1916. Fruit tree root systems: Spread and depth. Bulletin 143. Utah Agricultural Experiment Station. Logan, UT.

Bannan, M.W. 1940. The root systems of northern Ontario conifers growing in sand. American Journal of Botany 27(2):108-114.

Belsky, A.J. 1994. Influences of trees on savanna productivity: Tests of shade, nutrients, and tree-grass competition. Ecology 75(4):922-932.

Betanowny, K.H., and A.M.A. Wahab. 1973. Eco-physiological studies in desert plants. VIII. Root penetration of Leptadenia pyrotechnica (Forsk.) Decne. in relation to its water balance. Oecologia 11: 151-161.

Biswell, H.H. 1935. Effects of environment upon root habits of certain deciduous forest trees. Botanical Gazette 96(4):676-708.

Black, K.E., C.G. Harbron, M. Franklin, D. Atkinson, and J.E. Hooker. 1998. Differences in root longevity of some tree species. Tree Physiology 18(4):259-264.

Burger, D.W., and T.E. Prager. 2008. Deep-rooted trees for urban environments: Selection and propagation. Arboriculture and Urban Forestry 34(3):184-190.

Burgess, S.S.O., M.A. Adams, N.C. Turner, and C.K. Ong. 1998. The redistribution of soil water by tree root systems. Oecologia 115(3): 306-311.

Cable, D.R. 1977. Seasonal use of soil water by mature velvet mesquite. Journal of Range Management 30:4-11.

Cheyney, E.G. 1932. The roots of a jack pine tree. Journal of Forestry 30:929-932.

Clair, B., M. Fournier, M.F. Prevost, J. Beauchene, and S. Bardet. 2003. Biomechanics of buttressed trees: bending strains and stresses. American Journal of Botany 90(9):1349-1356.

Coile, T.S. 1937. Distribution of Forest Tree Roots in North Carolina Piedmont Soils. Journal of Forestry 35(3):247-257.

Crook, M.J., A.R. Ennos, and J.R. Banks. 1997. The function of buttress roots: a comparative study of the anchorage systems of buttressed (Aglaia and Nephelium ramboutan species) and non-buttressed (Mallotus wrayi) tropical trees. Journal of Experimental Botany 48(314):1703-1716.

Crow, P. 2005. The influence of soils and species on tree root depth. Information Note FCINO78 Forestry Commission Edinburgh 8 pp.

Davis, E.A., and C.P. Pase. 1977. Root system of shrub live oak: implications for water yield in Arizona chaparral. Journal of Water Conservation 32:174-180.

Dawson, T.E. 1993. Hydraulic lift and water-use by plants- implications for water-balance, performance and plant-plant interactions. Oecologia 95:565-574

Dawson, T.E. 1996. Determining water use by trees and forests from isotopic, energy balance and transpiration analyses: the roles of tree size and hydraulic lift. Tree Physiology 16(1-2):263-272. 
Day, S.D., and J.R. Harris. 2008. Growth, survival, and root system morphology of deeply planted Corylus colurna seven years after transplanting and the effects of root collar excavation. Urban Forestry \& Urban Greening 7(2):119-128.

Day, S.D., J.R. Seiler, and N. Persaud. 2000. A comparison of root growth dynamics of silver maple and flowering dogwood in compacted soil at differing soil water contents. Tree Physiology 20(4):257-263.

Day, S.D., G.W. Watson, P.E. Wiseman, and J.R. Harris. 2009. Causes and consequences of deep structural roots in urban trees: From nursery production to landscape establishment. Arboriculture and Urban Forestry 35(4):182-190.

Di Iorio, A., B. Lasserre, G.S. Scippa, and D. Chiantante. 2005. Root system architecture of Quercus pubescens trees growing on different sloping conditions. Annals of Botany 95:351-361.

Elmendorf, W., H.D. Gerhold, and L. Kuhns. 2005. A guide to preserving trees in development projects. Vol. 2009. Penn State College of Agricultural Sciences, Agriculture Research and Cooperative Extension. $<$ http://pubs.cas.psu.edu/FreePubs/pdfs/uh122.pdf>.

Fahey, T.J., and J.W. Hughes. 1994. Fine root dynamics in a northern hardwood forest ecosystem, Hubbard Brook Experimental Forest, NH. Journal of Ecology 82(3):533-548.

Gary, H.L. 1963. Root distribution of five-stamen tamarisk, seepwillow and arrowweed. Forestry Science 9:311-314.

Gasson, P.E., and D.F. Cutler. 1990. Tree root plate morphology. Arboricultural Journal: The International Journal of Urban Forestry 14(3):193-264.

Gerhold, H.D., and A.D. Johnson. 2003. Root dimensions of landscape tree cultivars. Journal of Arboriculture 29(6):322-326

Ghani, M.A., A. Stokes, and T. Fourcaud. 2009. The effect of root architecture and root loss through trenching on the anchorage of tropical urban trees (Eugenia grandis Wight). Trees: Structure and Function 23(2):197-209.

Gilman, E. 1988. Predicting root spread from trunk diameter and branch spread. Journal of Arboriculture 14(4):85-89.

Gilman, E.F. 1990. Tree root growth and development. I. Form, spread, depth and periodicity. Journal of Environmental Horticulture $8(4): 215-220$

Gilman, E.F. 2003. Where are tree roots? University of Florida, IFAS Extension, Gainesville, FL.

Glover, P.E. 1952. The root system of some Bristish Somaliland plants. IV. East African Agricultural Journal 17:38-50.

Guo, D., M. Xia, W. Xing , W. Chang, Y. Liu, and Z. Wang. 2008. Anatomical traits associated with absorption and mycorrhizal colonization are linked to root branch order in twenty-three Chinese temperate tree species. New Phytologist 180(3):673-683.

Harris, R., J. Clark, and N. Matheny. 2004. Arboriculture: Integrated Management of Landscape Trees, Shrubs, and Vines. 4th edition. Prentice Hall, Upper Saddle River, NJ.

Hawver, G., and N. Bassuk. 2006. Soils: The key to successful establishment of urban vegetation. pp. 137-152. In: Handbook of urban and community forestry in the Northeast. 2nd edition. J.E. Kuser (Ed.). Springer Publishing.

Hellmers, H., J.S. Horton, G. Juhren, and J. O'Keefe. 1955. Root systems of some chaparral plants in southern California. Ecology 36(4): 667-678.

Henwood, K. 1973. A structural model of forces in buttressed tropical rain forest trees. Biotropica 5(2):83-93.

Hewitt, A., and G. Watson. 2009. Nursery production can alter tree root architecture. Journal of Environmental Horticulture 27:99-104.
Hirano, Y., M. Dannoura, K. Aono, T. Igarashi, M. Ishii, K. Yamase, N. Makita, and Y. Kanazawa. 2009. Limiting factors in the detection of tree roots using ground-penetrating radar. Plant and Soil 319:15-24.

Hook, D.D. and C.L. Brown. 1973. Root adaptations and relative flood tolerance of five hardwood species. Forest Science 19(3):225-229.

Hosner, J.F. 1960. Relative tolerance to complete inundation of fourteen bottomland tree species. Forest Science 6(3):246-251.

Huante, P., E. Rincón, and F.S. Chapin Iii. 1998. Foraging for nutrients, responses to changes in light, and competition in tropical deciduous tree seedlings. Oecologia 117(1):209-216.

Jackson, R.B., L.A. Moore, W.A. Hoffmann, W.T. Pockman, and C.R. Linder. 1999. Ecosystem rooting depth determined with caves and DNA. Proceedings of the National Academy of Science USA 96:11387-11392.

Junqueras, R., A. March i Raurell, J. Chueca, and X. Fabregas i Bargallo. 2000. Respuesta de Celtis australis a mejoras en el suelo. Libro de ponencias del IV congreso ISA Europa y V Español de Arboricultura: 299-305.

Kozlowski, T., and S. Pallardy. 1997. Physiology of Woody Plants. 2nd edition. Academic Press, San Diego, CA.

Lyford, W.H., and B.F. Wilson. 1964. Development of the root system of Acer rubrum L. Harvard Forest Paper 10 Havard University Petersham, MA 17.

Marrotte, E.L. undated. Fertilization of Trees, Shrubs, Vines and Groundcovers. Vol. 2009. University of Connecticut Cooperative Extension $<$ http://www.hort.uconn.edu/Ipm/homegrnd/htms/41 fert.htm>

Marschner, H. 1996. Mineral Nutrition in Higher Plants. Academic Press, London.

Martin, P.H., and P.L. Marks. 2006. Intact forests provide only weak resistance to shade-tolerant invasive Norway maple (Acer platanoides L.). Journal of Ecology 94:1070-1079.

Mattheck, C. 1991. Trees: The Mechanical Design. Springer, Berlin.

McQuilkin, W.E. 1935. Root development of pitch pine, with some comparative observations on shortleaf pine. Journal of Agricultural Engineering Research 51:983-1016.

Mordelet, P., S. Barot, and L. Abbadie. 1996. Root foraging strategies and soil patchiness in a humid savanna. Plant and Soil 182(1):171-176.

Mou, P., R.J. Mitchell, and R.H. Jones. 1997. Root distribution of two tree species under a heterogeneous nutrient environment. Journal of Applied Ecology 34(3):645-656.

Mulatya, J M., J. Wilson, C K. Ong, J.D. Deans, and J.I. Sprent. 2002. Root architecture of provenances, seedlings and cuttings of Melia volkensii: implications for crop yield in dryland agroforestry. Agroforestry Systems 56(1):65-72.

Nadezhdina, N., and J. Cermak. 2003. Instrumental methods for studies of structure and function of root systems of large trees. Journal of Experimental Botany 54(387):1511-1521.

Nilsen, E.T., W.M. Jarrell, and R.A. Virginia. 1983. Diurnal and seasonal water relations of the desert phreatotype Prosopis glandulosa (honey mesquite) in the Sonoral Desert of California. Ecology 64: 1381-1393.

Patterson, J.C. 1977. Soil compaction: Effects on urban vegetation. Journal of Arboriculture 3(9):161-167.

Perry, T.O. 1982. The ecology of tree roots and the practical significance thereof. Journal of Arboriculture 8(8):197-211.

Pregitzer, K.S. 2002. Fine roots of trees - a new perspective. New Phytologist 154(2):267-273.

Pregitzer, K.S., J.L. DeForest, A.J. Burton, M.F. Allen, R.W. Ruess, and R.L. Hendrick. 2002. Fine root architecture of nine North American trees. Ecological Monographs 72(2):293-309. 
Pregitzer, K.S., M.J. Laskowski, A.J. Burton, V.C. Lessard, and D.R. Zak. 1998. Variation in sugar maple root respiration with root diameter and soil depth. Tree Physiology 18(10):665-670.

Rahjardo, H., F.R. Harnas, E.C. Leong, P.Y. Tan, Y.K. Fong, and E.K. Sim. 2009. Tree stability in an improved soil to withstand wind loading. Urban Forestry \& Urban Greening In Press.

Randrup, T.B., E.G. McPherson, and L.R. Costello. 2001. Tree root intrusion in sewer systems: review of extent and costs. Journal of Infrastructure Systems 7(1):26-31.

Rigg, G.B., and E.S. Harrar. 1931. The root systems of trees growing in sphagnum. American Journal of Botany 18(6):391-397.

Roberts, J. 1976. A study of root distribution and growth in a Pinus sylvestris L. (Scots pine) plantation in Thetford Chase, Anglia. Plant and Soil 44:607-621.

Rolf, K. 1991. Soil improvement and increased growth response from subsoil cultivation. Journal of Arboriculture 17(7):200-204.

Schenk, H.J.a.R.B.J. 2002. Rooting depths, lateral root spreads and below-ground/above ground allometries of plants in water-limited ecosystems. Journal of Ecology 90(3):480-494.

Schroeder, K. 2005. Konkurrenz unter Tage [Competition underground]. GruenForum.LA 4:34-38.

Smith, J.H.G. 1964. Root spread can be estimated from crown width of Douglas fir, lodgepole pine, and other British Columbia tree species. The Forestry Chronicle 40(4):456-473.

Smith, W.H. 1976. Character and significance of forest tree root exudates. Ecology 57(2):324-331.

Stokes, A., A.H. Fitter, and M.P. Coutts. 1995. Responses of young trees to wind and shading: Effects on root architecture. Journal of Experimental Botany 46(9):1139-1146.

Stone, E.L., and P.J. Kalisz. 1991. On the maximum extent of tree roots. Forest Ecology and Management 46(1-2):59-102.

Stransky, J.J. 1990. Quercus stellata Wangenh.--post oak. pp. 738-743 In: Silvics of North America: Volume 2. Hardwoods. Vol. Agriculture Handbook 654. R.M. Burns and B.H. Honkala (Ed.) United States Department of Agriculture (USDA), Forest Service.

Strong, W.L., and G.H. LaRoi. 1983. Root system morphology of common boreal forest trees in Alberta. Canadian Journal of Forest Research 13:1160-1173.

Sutton, R.F., and R.W. Tinus. 1983. Root and root system terminology. Forest Science 29(4):supplement (Monograph 24).

Tolle, H. 1967. Durchwurzelungsverhaitnisse mittelalter Kieferbestande [Rooting conditions of mid-age pine stands]. Archiv fuer Forstwesen 16:775-779.

Tubbs, C.H. 1977. Root-crown relations of young sugar maple and yellow birch. Research Note NC-225. USDA Forest Service, North Central Forest Experiment Station.

Wang, Z., D. Guo, X. Wang, J. Gu, and L. Mei. 2006. Fine root architecture, morphology, and biomass of different branch orders of two Chinese temperate tree species. Plant and Soil 288(1):155-171.

Watson, G.W., and E.B. Himelick. 1982. Root distribution of nursery trees and its relationship to transplanting success. Journal of Arboriculture 8(9):225-229.

Wilson, B. F. 1964. Structure and growth of woody roots of Acer rubrum L. Harvard Forest Paper 11 Harvard University Petersham, MA 14.

Wong, W., Y. Jio, L. Xu, and Z. Zhong. 1997. Study on the root distribution of Populus tomentosa. Journal of the Agricultural University of Hebei Vol. 01.

Yamashita, M., T. Takyu, and T. Sasa. 1997. Gravitropic reaction in the growth of tea roots. Nihon Sakumotsu Gakkai Kiji 66:472-478.
Susan D. Day (corresponding author)

Assistant Professor

Department of Forest Resources \& Environmental Conservation and Department of Horticulture

Virginia Tech

310 Cheatham Hall (0324)

Blacksburg, Virginia 24061, U.S.

sdd@vt.edu

\section{P. Eric Wiseman}

Assistant Professor

Department of Forest Resources \& Environmental Conservation Virginia Tech

228 Cheatham Hall (0324)

Blacksburg, Virginia 24061, U.S.

Sarah B. Dickinson

Research Associate

Department of Horticulture

Virginia Tech

301 Saunders Hall (0327)

Blacksburg, Virginia 24061, U.S.

\section{J. Roger Harris}

Professor

Department of Horticulture

Virginia Tech

301 Saunders Hall (0327)

Blacksburg, Virginia 24061, U.S. 
Résumé. La connaissance de l'étendue et de la distribution du système racinaire d'un arbre est essentielle pour la gestion des arbres dans un environnement construit. En dépit des récentes avancées en matière d'outil de détection des racines, la recherche publiée dans l'architecture des racines d'un arbre en milieu urbain est limitée et a été seulement partiellement synthétisée. Les patrons de croissance des racines d'arbres urbains peuvent considérément différer entre des espèces similaires dans des environnements forestier ou agricole. Dans cet article, nous effectuons une revue de la littérature documentant la croissance des racines chez les arbres en milieu urbain tout comme la littérature qui traite de l'architecture des racines en environnement non urbain et qui pourrait contribuer à notre compréhension des racines d'arbres au sein des environnements construits. Même si les espèces d'arbres peuvent avoir le potentiel génétique pour générer des systèmes racinaires en profondeur $(>2 \mathrm{~m}$ ), la profondeur des racines en milieux urbains est souvent restreinte par des couches de sols impénétrables ou inhospitalières ou encore par l'infrastructure souterraine. Le développement latéral des racines est généralement restreint par des sols denses sous des surfaces en dur ou par l'absence d'irrigation dans des zones sèches. En combinant les résultats de plusieurs études, nous avons estimé que le rayon d'un système racinaire sans restriction augmentait initialement à un taux de 38 pour 1 comparativement au diamètre du tronc, mais que ce ratio déclinait considérablement avec la maturation de l'arbre. Les racines sont souvent distribuées de manière irrégulière atour de l'arbre et peuvent être influencées par la direction cardinale, le terrain, l'inclinaison de l'arbre ou les obstacles dans un environnement construit. Les racines en contrefort, les pivots racinaires et les autres types de racines font aussi l'objet d'une discussion.

Zusammenfassung. Die Kenntnis über die Ausdehnung und Verteilung eines Baumwurzelsystems ist für die Verwaltung von Bäumen in urbanen Raum notwendig. Unabhängig von jüngsten Fortschritten bei Wurzelfinder-Werkzeugen, ist die bislang publizierte Forschung über Wurzelsysteme von urban wachsenden Bäumen begrenzt und nur teilweise angeglichen. Wurzelwachstumsstrukturen von Stadtbäumen können erheblich von denen in der freien Landschaft oder Wald wachsenden Bäumen abweichen. In dieser Studie geben wir einen Literaturüberblick zur Dokumentation von Wurzelwachstum in der Stadt und auch Literatur über Wurzelarchitektur in freier Landschaft, wie etwas zum allgemeinen Verständnis beitragen kann. Obwohl Baumarten ein genetisches Poten- tial zur Entwicklung eines tiefen Wurzelsystems ( $>2 \mathrm{~m}$ ) haben können, ist die Wurzeltiefe in urbanen Räumen gelegentlich begrenzt durch undurchdringbare oder ungastliche, verdichtete Bodenschichten oder durch eine Untergrundbebauung. Die laterale Wurzelausdehnung ist ebenfalls beschränkt durch dichte Böden oder Wassermangel. Wenn die Ergebnisse der zahlreichen Studien zusammengeführt werden, so schätzen wir, daß der Radius eines unbeschränkt wachsenden Wurzelsystems zunimm mit einer Rate von 38 zu 1, verglichen mit dem Stammdurchmesser, aber dieses Verhältnis nimmt mit zunehmendem Baumalter rapide ab. Wurzeln sind oft unregelmässig um den Baum verteilt und können durch die Hauptrichtung, Gelände, Baumneigung oder Obstruktionen in urbanem Umfeld beeinflusst werden. Stützwurzeln, Saugwurzeln und andere Wurzeltypen werden ebenfalls diskutiert.

Resumen. El conocimiento de la extensión y distribución de los sistemas de raíces es esencial para el manejo de los árboles en el ambiente urbano. A pesar de los avances recientes en herramientas de detección de raíces, las investigaciones publicadas en la arquitectura de las raíces de los árboles en ambientes urbanos han estado limitadas en solamente síntesis parcializadas. Los patrones de crecimiento de las raíces de los árboles urbanos pueden diferir considerablemente de especies similares en ambientes agrícolas o forestales. En este reporte se revisó la literatura documentando el crecimiento de las raíces de los árboles en ambientes urbanos como también la literatura de ambientes no urbanos que pueden contribuir al entendimiento de las raíces de los árboles en ambientes construidos. A pesar de que las raíces de los árboles pueden tener el potencial genético para la generación de sistemas de raíces profundos $(>2 \mathrm{~m})$, el crecimiento en situaciones urbanas está frecuentemente restringido por la impenetrabilidad o inhospitalidad de las capas de suelo o por la infraestructura subterránea. La extensión lateral de las raíces está de alguna manera sujeta a restricción por suelos densos abajo o por la ausencia de riego en áreas secas. Por combinación de resultados de numerosos estudios, se estimó que el radio de un sistema de raíz incrementa inicialmente a la tasa de aproximadamente 38 a 1, comparado al diámetro del tronco, pero esta relación parece declinar considerablemente a medida que el árbol madura. Las raíces están frecuentemente distribuidas irregularmente alrededor del árbol y pueden ser influidas por la dirección cardinal, terreno, inclinación del árbol, u obstáculos en el ambiente construido. Se discuten también las raíces de anclaje, las pivotantes y otros tipos. 


\section{APPENDIX}

Reports of root system maximum depth and radius and tree height and trunk diameter. Data represent mean measurements of individual trees as reported by the authors. Data analysis is presented in Figure 1 and Figure 2.

\begin{tabular}{|c|c|c|c|c|c|c|c|}
\hline Family & Species & $\begin{array}{l}\text { Mean Tree } \\
\text { Height }(\mathrm{m})\end{array}$ & $\begin{array}{l}\text { Mean Max. } \\
\text { Root Depth } \\
\quad(\mathrm{m})\end{array}$ & $\begin{array}{l}\text { Mean Trunk } \\
\text { Diameter } \\
(\mathrm{cm})\end{array}$ & $\begin{array}{l}\text { Mean Max. } \\
\text { Root Radius } \\
\quad(\mathrm{m})\end{array}$ & $\begin{array}{l}\text { Number } \\
\text { of trees } \\
\text { measured } \\
(\mathrm{N})\end{array}$ & Reference \\
\hline Cupressaceae & Thuja plicata Donn. & 9 & & & 6.4 & & (Rigg and Harrar 1931) \\
\hline Pinaceae & Picea glauca (Moench) Voss & 12 & 1.4 & & 18.6 & & (Bannan 1940) \\
\hline Pinaceae & Pinus banksiana Lamb. & 14 & 2.1 & & 8.5 & 1 & (Cheyney 1932) \\
\hline Pinaceae & Pinus banksiana Lamb. & 18 & 2 & & 14 & 8 & (Strong and LaRoi 1983) \\
\hline Pinaceae & Pinus contorta Doug. & 2.4 & & & 7 & & (Rigg and Harrar 1931) \\
\hline Pinaceae & Pinus monticola Dougl. & 11 & & & 7 & & (Rigg and Harrar 1931) \\
\hline Pinaceae & Pinus monticola Dougl. & 18 & & & 14.2 & & (Rigg and Harrar 1931) \\
\hline Pinaceae & Pinus rigida Mill. & 7 & 2.7 & & & & $\begin{array}{l}\text { (McQuilkin 1935) as } \\
\text { cited in Stone and } \\
\text { Kalisz (1991) }\end{array}$ \\
\hline Pinaceae & Pinus sylvestris $\mathrm{L}$. & 26 & 2 & & & & $\begin{array}{l}\text { (Tolle 1967) as cited in } \\
\text { Stone and Kalisz (1991) }\end{array}$ \\
\hline Pinaceae & Tsuga heterophylla (Raf.) Sarg. & 6 & & & 10 & & (Rigg and Harrar 1931) \\
\hline Aceraceae & Acer rubrum L. & & & 7.4 & 2.75 & 25 & (Gilman 1988) \\
\hline Betulaceae & Alnus rubra Bong. & 28.35 & & 41.66 & 4.88 & 33 & (Smith 1964) \\
\hline Cupressaceae & Thuja plicata Donn. & 35.05 & & 68.58 & 5.18 & 61 & (Smith 1964) \\
\hline Fabaceae & Acacia bussei Harms & 4 & & & 14 & & $\begin{array}{l}\text { (Glover 1952) as cited in } \\
\text { Stone and Kalisz (1991) }\end{array}$ \\
\hline Fabaceae & Acacia mellifera Benth. & 4 & & & 15 & & $\begin{array}{l}\text { (Adams 1966) as cited in } \\
\text { Stone and Kalisz (1991) }\end{array}$ \\
\hline Fabaceae & Acacia seyal Del. & 7 & 1.2 & & 8 & & $\begin{array}{l}\text { (Adams 1966) as cited in } \\
\text { Stone and Kalisz (1991) }\end{array}$ \\
\hline Fabaceae & $\begin{array}{l}\text { Dipteryx panamensis (Pittier) } \\
\text { Record }\end{array}$ & 30 & 5 & & & & $\begin{array}{l}\text { R.F. Fisher (personal } \\
\text { communication, 1988) } \\
\text { as cited in Stone and } \\
\text { Kalisz (1991) }\end{array}$ \\
\hline Fabaceae & $\begin{array}{l}\text { Gleditsia triacanthos var. } \\
\text { inermis (L.) C.K. Schneid. }\end{array}$ & & & 8 & 2.75 & 6 & (Gilman 1988) \\
\hline Fabaceae & $\begin{array}{l}\text { Leptadenia pyrotechnica (Forsk.) } \\
\text { Decne. }\end{array}$ & 2 & 11.5 & & 5 & & $\begin{array}{l}\text { (Betanowny and Wahab } \\
\text { 1973) as cited in Stone } \\
\text { and Kalisz (1991) }\end{array}$ \\
\hline Fabaceae & $\begin{array}{l}\text { Prosopis 'juliflora' (Swartz) DC. } \\
\text { (= P. glandulosa?) }\end{array}$ & 6 & 3 & & 19 & 4 & (Cable 1977) \\
\hline Fagaceae & Quercus macrocarpa Michx. & 3.6 & 4.4 & & 3.3 & 3 & (Biswell 1935) \\
\hline Fagaceae & Quercus turbinella Greene & 2.4 & 6.4 & & & 1 & (Davis and Pase 1977) \\
\hline Fagaceae & Quercus virginiana Mill. & & & 6.5 & 2.3 & 25 & (Gilman 1988) \\
\hline Magnoliaceae & Magnolia grandiflora $\mathrm{L}$. & & & 7.5 & 3 & 25 & (Gilman 1988) \\
\hline Oleaceae & Fraxinus pennsylvanica Marsh. & & & 7.5 & 1.8 & 6 & (Gilman 1988) \\
\hline Oleaceae & Syringa reticulata 'Ivory Silk' & 3.67 & 0.59 & 6.65 & 2.79 & 5 & $\begin{array}{l}\text { (Gerhold and Johnson } \\
\text { 2003) }\end{array}$ \\
\hline Oleaceae & Syringa reticulata 'Ivory Silk' & 4.57 & 0.5 & 10.46 & 4.02 & 5 & $\begin{array}{l}\text { (Gerhold and Johnson } \\
\text { 2003) }\end{array}$ \\
\hline Pinaceae & Pseudotsuga menziesii (Mirb) & 36.88 & & 58.42 & 5.49 & 89 & (Smith 1964) \\
\hline Pinaceae & Tsuga heterophylla (Raf.) Sarg. & 42.98 & & 66.04 & 5.49 & 81 & (Smith 1964) \\
\hline Rosaceae & Adenostoma fasciculatum H.\&A. & 1.5 & 7.6 & & 3.7 & 13 & (Hellmers et al. 1955) \\
\hline Rosaceae & Amelanchier Autumn Brilliance ${ }^{\circledR}$ & 3.83 & 0.25 & 3.86 & 1.98 & 5 & $\begin{array}{l}\text { (Gerhold and Johnson } \\
\text { 2003) }\end{array}$ \\
\hline Rosaceae & Amelanchier 'Cumulus' & 6.41 & 0.69 & 16.08 & 4.06 & 6 & $\begin{array}{l}\text { (Gerhold and Johnson } \\
\text { 2003) }\end{array}$ \\
\hline Rosaceae & Amelanchier 'Snowcloud' & 4.03 & 0.48 & 4.16 & 0.896 & 5 & $\begin{array}{l}\text { (Gerhold and Johnson } \\
\text { 2003) }\end{array}$ \\
\hline Rosaceae & Malus Harvest Gold ${ }^{\circledR}$ & 4.38 & 0.68 & 7.11 & 2.71 & 5 & $\begin{array}{l}\text { (Gerhold and Johnson } \\
\text { 2003) }\end{array}$ \\
\hline Rosaceae & Malus 'Professor Sprenger' & 3.02 & 0.35 & 3.81 & 2.4 & 5 & $\begin{array}{l}\text { (Gerhold and Johnson } \\
\text { 2003) }\end{array}$ \\
\hline Rosaceae & Pyrus calleryana 'Autumn Blaze' & 3.57 & 0.6 & 4.62 & 2.23 & 5 & $\begin{array}{l}\text { (Gerhold and Johnson } \\
\text { 2003) }\end{array}$ \\
\hline
\end{tabular}


APPENDIX continued.

\begin{tabular}{|c|c|c|c|c|c|c|c|}
\hline Family & Species & $\begin{array}{l}\text { Mean Tree } \\
\text { Height (m) }\end{array}$ & $\begin{array}{l}\text { Mean Max. } \\
\text { Root Depth } \\
\quad(\mathrm{m})\end{array}$ & $\begin{array}{l}\text { Mean Trunk } \\
\text { Diameter } \\
(\mathrm{cm})\end{array}$ & $\begin{array}{l}\text { Mean Max. } \\
\text { Root Radius } \\
\quad(\mathrm{m})\end{array}$ & $\begin{array}{l}\text { Number } \\
\text { of trees } \\
\text { measured } \\
(\mathrm{N})\end{array}$ & Reference \\
\hline Rosaceae & Pyrus calleryana Chanticleer ${ }^{\circledR}$ & 3.83 & 0.55 & 5.28 & 1.56 & 5 & $\begin{array}{l}\text { (Gerhold and Johnson } \\
\text { 2003) }\end{array}$ \\
\hline Rosaceae & Pyrus communis L. (H) & 3.3 & 2.7 & & 3 & & $\begin{array}{l}\text { (Ballantyne 1916) as } \\
\text { cited in Stone and } \\
\text { Kalisz (1991) }\end{array}$ \\
\hline Salicaceae & Populus $\times$ generosa & & & 11.9 & 3.75 & 6 & (Gilman 1988) \\
\hline Salvadoraceae & Dobera glabra A. DC. & 2.7 & 12 & & & & $\begin{array}{l}\text { (Glover 1952) as cited in } \\
\text { Stone and Kalisz (1991) }\end{array}$ \\
\hline Tamaricaceae & Tamarix pentatandra Pallas & 5 & 3.7 & & 3.3 & & $\begin{array}{l}\text { (Gary 1963) as cited in } \\
\text { Stone and Kalisz (1991) }\end{array}$ \\
\hline Ulmaceae & Celtis australis & & & 19.1 & 4 & 35 & (Junqueras et al. 2000) \\
\hline
\end{tabular}

